\title{
TENAGA KERJA DALAM REVOLUSI INDUSTRI 4.0
}

\section{References}

\author{
Ahmad Zafrullah Tayibnapis, L. E. (August 2018). Indonesia's Efforts to Achieve Globally Competitive \\ Human. International Journal of Humanities and Social Science Invention, 01-06.
}

Perekonomian di Indonesia meningkat sebanyak 5\% di tahun 2016, 2017 dan 2018. Para pakar ekonomi memperkirakan bahwa di tahun 2020 perekonomian di Indonesia akan meningkat sebanyak $1 \%$, dari yang sebelumnya $5 \%$ menjadi $6 \%$ per tahunnya. Semua itu diperkirakan karena Indonesia mampu memperkuat pengelolaan makroekonomi dan mempercepat sejumlah proyek strategis nasional. Sebelumnya, pemerintah merencanakan untuk membangun industry manufaktur yang memiliki daya saing global dengan menerapkan industry 4.0, karena industry nasional membutuhkan koneksi dan interaksi menggunakan teknologi dan komunikasi yang lebih efisien dan modern untuk mempermudah dalam pencapaian tujuan yang diinginkan. Revolusi industri 4.0 ditandai dalam menggunakan teknologi informasi, kecerdasan buatan, dan mesin atau kendaraan otomatis yang sudah digunakan sejak tahun 2011, dimana mesin-mesin tersebut telah di perbarui dengan bantuan internet, bahkan beberapa negara sudah menemukan cara yang lebih efisien dengan memperbarui sistem produksi industri dengan penuh perjuangan. Misal, dalam industry otomotif membutuhkan teknologi informasi untuk mempermudah dalam hal penelitian, pengembangan dan desain dalam membuat suatu produk, mendistribusi, menjual, bahkan dalam mendaur ulang. Beberapa industri otomotif di Indonesia memanfaatkan teknologi agar lebih efisien, teknologi yang biasa digunakan adalah teknologi untuk mencetak tiga dimensi dan teknologi robotic. Pelaku usaha sangat membutuhkan keunggulan untuk bisa bersaing di pasar global saat ini ataupun nanti di masa depan. Karena teknologi semakin lama semakin canggih dan semakin efisien, maka pelaku usaha harus bisa memutar otak agar tidak kalah saing dalam hal teknologi. Transformasi yang besar dalam semua tingkatan dan unit usaha terjadi karena setiap pelaku usaha bisa memasuki pasar negara lain (selain negaranya sendiri) dengan sangat mudah, karena tidak adanya batasan yang nyata. Sehingga pelaku usaha dituntut untuk bisa lebih professional dalam mengambil keputusan dalam bisnisnya dan dapat berinovasi dengan baik kedepannya. Agar perusahaan bisa terus berinovasi adalah siap untuk menyiapkan dan membangun sumber daya manusia yang unggul, memiliki telanta dengan standar kompetensi yang tinggi di bidangnya masing- masing dan memiliki karakter yang dapat bersaing secara global. Indonesia dihitung sangat membutuhkan sumber daya manusia yang unggul karena adanya revolusi industri 4.0 yang mengubah pandangan politik dan juga ekonomi yang mengakibatkan banyaknya pekerja yang tergantikan oleh teknologi (mesin). Penggunaan teknologi mesin otomatis mungkin akan mengurangi jumlah tenaga kerja lama, namun bisa membuka lapangan kerja yang baru. Penggunaan mesin otomatis juga bermanfaat untuk meningkatkan produktivitas dan menurunkan peningkatan biaya produksi.

Produktivitas karyawan berbanding lurus dengan tingginya daya saing dalam persaingan bisnis, karena tingkat kepuasan setiap perusahaan berbeda-beda. Suatu perusahaan bisa memberi gaji yang sepadan dengan hasil kerja, jaminan karir yang lebih baik, lingkungan kerja yang 
nyaman, dan sejumlah fasilitas yang ditawarkan juga sepadan. Biasanya perusahaan tersebut berekspetasi mempunyai karyawan yang kompeten dan mampu berkomitmen pada perusahaan tersebut. Perusahaan yang unggul biasanya bisa beradaptasi dengan adanya perubahan dan kompetitif. Perkembangan era global yang semakin hari semakin meningkat, maka perusahaan seharusnya bisa berubah dan bertahan secara konsisten. Perusahaan merubah dengan meninggalkan cara yang lama dan menggunakan metode yang baru dan lebih efisien. Tentu saja perubahan dan metode yang baru dalam suatu perusahaan juga terkait dengan sumber daya manusianya. Semua perubahan akan berjaan dengan baik apabila memiliki organisasi yang kuat. Perlunya sistem seleksi karyawan yang tepat dan dikembangkan lagi sesuai dengan adanya lapangan pekerjaan. Pengembangan tersebut biasanya dilakukan melalui kegiatan pelatihan dan memahami budaya perusahaan untuk meningkatkan pengetahuan dan keterampilan karyawan. Pelatihan tersebut bertujuan agar karyawan baru atau lama bisa mendapatkan keterampilan yang mereka butuhkan dalam melaksanakan perkerjaan saat ini, sedangkan pengembangan karyawan dan juga manajemen merupakan pelatihan jangka panjang untuk mempermudah pemecahan masalah dalam suatu organisasi. Prestasi yang dicapai karyawan harus selalu ditingkatkan agar tidak kalah saing. Kompensasi yang diberikan harus mengikuti harga pasar agar dapat memotivasi karyawan untuk bekerja lebih baik lagi. Pelatihan dan pengembangan sumber daya manusia diterapkan agar manusia tidak kalah dengan majunya tekonologi, munculnya teknologi yang lebih modern, lebih menguntungkan, dan lebih efisien untuk perusahaan tidak ditujukan agar sumber daya manusia semakin sedikit. Namun melatih sumber daya manusia atau karyawan agar bisa berdampingan dengan majunya teknologi, adanya mesin-mesin yang canggih mempermudah pekerjaan tenaga kerja. Mungkin suatu perusahaan akan mengurangi jumlah karyawan di perusahannya karena adanya mesin baru yang lebih canggih dan efisien dari pekerjaan manusia. Tetapi perusahaan tersebut bisa membuka lapangan pekerjaan lain yang sumber daya manusia nya bisa berdampingan dengan teknologi.

\section{Putu Setyarini 130118902}

